\title{
Young Mothers, Concrete Cages: Representations of Maternity in Hungarian Housing Films from the 1970s and $1980 \mathrm{~s}$
}

\author{
Zsolt Györi
}

\begin{abstract}
The chapter examines state socialist spaces of communal living from a gender perspective using relevant Hungarian films. Informed by Judit Ember's Fagyöngyök (Mistletoes, 1978), Béla Tarr's Családi tüzfészek (Family Nest, 1979) and Panelkapcsolat (The Prefab People, 1982), and György Szomjas' Falfúró (Wall Driller, 1985) I argue that highrise blocks of flats might have eased the housing shortage brought about by socialist industrialization, they hardly achieved social or gender equality. Emphasizing the resistance of the selected films to play along the official ideological-utopian discourse surrounding housing policies, I point out the collaboration between the paternalistic and the patriarchal regimes, most evident in the subordination of welfare policies to national economic considerations that privilege male control and ensure female subordination in the home. Cinema is a useful tool to study "architectural patriarchy" as it both captures the gendered affective imaginations females and males invest in space and portrays marital relationships as a site of inequality, identity crisis, and (female) entrapment. The second part of the chapter distinguishes between three psychodynamically invested social environments - that of the neighbourhood, the extended family, and the nuclear family (mainly the relationship between spouses) - and offers a close reading of how cinema renders legible the character's affective investments in space through describing their varied associations with patriarchy.
\end{abstract}

${ }_{5} \mathrm{C}_{1} \quad 1 \quad$ Introduction and the Scope of the Research

This chapter explores Hungarian cinematic narratives of family and community life set in housing complexes consisting of concrete tower blocks ${ }^{1}$ in the late

1 For definitions, I rely on concepts as defined by Tamás Egedy, based on relevant explications of the Hungarian Central Statistical Office. Egedy defines housing complexes of concrete tower buildings as "separate communes within the administrative region of the 
socialist period. A general trait and joint motif of the chosen films is their focus on young mothers reliant on their spouses both for income and emotional support to counter the negative psychological effects of postpartum depression, child-raising (for example, exhaustion, anxiety, frustration, low self-esteem), social withdrawal and alienation, monotonous chores, and the financial pressure to make ends meet.

While mapping the physical and affective space of the home in statesocialist Hungary, the films share a common ground with what Edward W. Soja called spatial imagination, a critical perspective no longer "subordinated to the dominant dialectic of historicality-sociality, the interplay between what might more collectively be called the making of histories and the constitution of societies" (262). My examples of housing films - Béla Tarr's Családi tüzfészek (Family Nest, 1979) and Panelkapcsolat (The Prefab People, 1982), and György Szomjas' Falfúró (Wall Driller, 1985) - use the spatial representations of cinema to contest official and dominant perceptions of communal living as a great historical and social achievement to resolve the housing shortage brought about by socialist industrialization. Although the urban housing developments during the 1970s resulted in the construction of the highest number of apartment units per decade in 2oth-century Hungary, the contradiction between quantity and quality, as Henri Lefebvre also noted in regard to the social production of space, surfaced: "the dominant tendency, therefore is towards the disappearance of the qualitative" (352). The first sociological accounts of the process of ghettoization, revolving around - as Sándor Horváth notes - the metaphors of chaos and the labyrinth (88-90), stood in stark contrast with official narratives that celebrated the new districts as a decisive victory against destitution, crime, and vulnerability, while advertising this type of communal living as a privilege. ${ }^{2}$ Cinema stood opposed to such lofty and self-aggrandizing descriptions and, taking sides with sociological investigations as epitomized by the semi-sociographic films of the so-called Budapest School, rendered

settlement - usually surrounded by roadways - which hold a coherent whole of residential flats, buildings and civil engineering facilities ... Housing estates are situated common land, consist of multi-level residential buildings that were constructed according to central planning directives using model designs and organized labor force ... a group of medium high or high residential buildings and rows of apartment blocks constructed using the precast largepanel system." (translation mine) (Egedy Tamás "Kiskedvencből mostohagyerek? A lakótelepek helyzete." http://beszelo.c3.hu/o5/o304/1oegedy.htm).

2 Almost every chapter in the volume entitled Lakótelepek, a modernitás laboratóriumai (HighRise Districts, the Laboratories of Modernism) (Budapest: Kijárat Kiadó, 2008) makes reference to this narrative and points to the then-prevalent discourse which presented socialist urban modernization as an eminent area of tackling social problems. 
domestic space visible without either acknowledging its role in the liberation of the masses from the historical evils of rural poverty and bourgeois alienation, or recognizing socialist welfare reforms as a revolutionary step towards the eradication of social inequality. In fact, films offer symptomatic readings of the affective topography characterizing the estates and the identity crises of its tenants.

The films analyzed in this chapter were not the first to portray urban socialist spaces which challenge the ideologically framed official discourse. My previous research concentrated on how Hungarian cinema followed - from initial enthusiasm to gradual disillusionment - the transitions in public perceptions about this type of communal living. ${ }^{3}$ As I argued there, the key stage of this transformation occurred in the 1970s, most notably in Péter Bacsó's trilogy (The Agony of Mr. Boróka, 1972; Let Go of My Beard, 1975; A Piano in Mid Air, 1976), a cycle of satirical stories set in high rise housing estates, which capture the mind-frame of the "homo politicus sovieticus," the socialist version of the regime's dedicated devotee who echoed its empty phrases and stereotypes without self-reflection. Bacsó's films draw close parallels between the grey block-buildings of the estates and thinking through clichés; the spatial regulation of ideal living (confined to uniformly built, small apartments with low maintenance costs) and the psychology of the ideal communist. My choice of films favors realist representations over satirical ones which, furthermore, extend and refine the predominantly masculine experiences of identity crisis by foregrounding female anxieties and entrapment. Their engagement with spatiality, I argue, foregrounds a critical agency focusing on housing policies, which, alongside free education, healthcare, long maternity leave, childcare benefit, full-employment and a dual-breadwinner family model, was a key area of family and welfare reforms. As András Murai and Eszter Zsófia Tóth claim, the films in question "present the dependency of the individual on the system as a social problem" (10). In her exploration of the social policy, Katherine Verdery calls attention to the fact that the state socialist welfare state was another form of socialist paternalism which "presumed [subjects] to be grateful recipients - like small children in a family - of benefits their rulers decided upon for them. The subject disposition this produced was dependency, rather than the agency cultivated by citizenship or the solidarity of ethnonationalism" (Verdery 63) This was the case with pronatalist policies that, in theory, allowed for female emancipation and the equality of the two sexes, but in fact,

3 See "Concrete Utopias: Discourses of Domestic Space in Central Eastern European Cinema." In Spaces, Bodies, Memories, edited by Andrea Virginás. Newcastle upon Tyne: Cambridge Scholars Publishing, 2016. 28-49. 
narratives of lived space and "protagonists with limited room for maneuver and without perspective" (Murai-Tóth 10) often testify the failure of housing schemes to achieve either social or gender equality.

My focus on the affective dimension of young mothers' domestic entrapment extends but is also indebted to previous research that almost exclusively adopted sociological research methods and investigated the relationship between social status, education and income levels (Szelényi-Konrád; Egedy "A társadalmi kirekesztés"; Csizmady "Lakótelep és társadalmi szegregáció" and A lakótelep), poverty and social segregation (Egedy "A társadalmi kirekesztés" and "Kiskedvencből mostohagyerek?"; Csizmady "Lakótelep és társadalmi szegregáció" and A lakótelep), demography of tenants (Egedy "Kiskedvencből mostohagyerek?"; Csizmady A lakótelep), ethnic composition of tenants (Csizmady "Lakótelep és társadalmi szegregáció"; Egedy "Kiskedvencből mostohagyerek?") and the urban ecological effects of housing complexes (Bakay) The scope and nature of sociological inquiry leaves those aspects of lived space unexplored that are best made visible in long interviews or by the analysis of the then-contemporary discourse of young mothers' emotional frailty. David Crowley also relies on different sources, but with a similar message in his interpretation of the ordinary homes of state-socialist Warsaw housing schemes, arguing that "[a]rticles published in this medium represented not only the State's interest in disciplining the home, but also ... attempts to speak for the private a particular form of the 'publicity of the private' " (189). In Hungary, Eszter Zsófia Tóth's research into the gender politics of the Kádár-era takes this route, and reconstructs a series of debates between readers of the popular women's magazine, Nók Lapja (Women's Magazine) about the simultaneous presence of comfort and isolation, welfare and emotional impoverishment, boredom and tight schedules, saintliness and martyrdom in the lives of mothers with young children (154-163). Such debates, much the same as life story interviews, made visible contradictions that fade away or remain totally invisible within the framework of the standardized questions in qualitative research interviews. I contend that cinematic representations can be attributed a similar agency, especially since they explore the plight of women in housing complexes with emphasis on the affective layers of spatiality, including conflicts with neighbours, the lack of intimacy and the superior position of the breadwinner patriarch over inactive wives. In its spatial construction of domestic environment, cinema both captures the gendered affective imaginations females and males invest in space and stages marital relationships as a site of inequality, identity crisis, and entrapment. 


\section{Between Architecture and Patriarchy}

The most salient affective quality of housing complexes of pre-fabricated buildings is their vast proportions. Manufactured in factories and assembled on-site, they lend cityscapes an industrial touch: their coarse surfaces, uniform facades and dull colours evoke authority and anxiety in the onlooker. ${ }^{4}$ The Brutalist architectural features of these buildings emphasized but also celebrated the stark and self-assertive masculine labor required for their construction. Underlying the material-architectural appearance of these buildings, there is a gendered spatial logic described by Flanagan, Valiulis, and Gialanella:

every city is a gender regime that ideologically and concretely manifests a distinctive relationship among its political, economic, and familial systems. This gender regime is patriarchal: it reflects the social relations of power in any given society in which the values and behaviours of men are presumed normative and thus embedded in urban institutions and structures to privilege male control and insure female subordination.

In the present case, this subordination translates into women being made invisible and hidden in concrete cages which keep their bodies and emotional anxieties under male control. Taking into consideration the paternalistic logic of pro-natalist policies which, according to Verdery, "treated women's bodies as no more than instruments of the state's reproductive requirements" (65) these monochrome buildings could be likened to an incubator.

Although I perceive these homogenous-looking high-rise buildings as architectural symbols of young mothers' entrapment, other constraints need to be considered, including the uneven responsibilities towards domestic chores and the distortive stereotypes that overvalue the (male) breadwinner's role and undervalue that of the (female) homemaker's in supporting family life. Not only was society governed by "a paternalist regime that made the most important decisions in "the whole family's" interests" (Verdery 66) and forced maternal bodies into invisibility, but it also worked invisibly, enforcing normative notions of man/woman, father/mother in subtle ways, weaving gender

4 Developing Lefebvre' arguments, David Crowley points to similar tendencies in Warsaw housing projects: "in the Soviet-styled city, space was subordinate to images and effects, and, by the same system, interiors were inferior to the exterior forms that produced them. Space was impoverished by the political imperative to create a particular form of 'representational architecture'" (185). 
antagonisms and hierarchies into the texture of (banal) everyday rituals. A vivid illustration is the closing scene of Judit Ember's Fagyöngyök (Mistletoes, 1978), a semi-documentary portrayal of the quotidian domestic life of a young pregnant mother with two children and her spouse. Although the film points to the limits of patriarchy by presenting self-conscious female characters with remarkable willpower, stamina and playful ways to manipulate men, the concluding scene of the film demonstrates that the social visibility of new life is granted not in its intimate links to the corporeal space of the mother, but through a patriarchal discursive space which attributes meanings to it and symbolically calls it into being. The family gathering organized to welcome/ celebrate the newborn becomes an initiation ritual into the realm of visibility and meaningful subjecthood granted by patriarchy. This is also the space, then, where the intimate silence of the maternal body is broken by egotistic voices celebrating adult male virtues, which do not really toast the newborn, only themselves.

The head of the city council, a man of authority (speaking in private) lays the foundation of the discursive space, to which all subsequent addresses will accommodate: he wishes the baby "to grow into an immaculately honest, strong adult male." The godfather speaks next - "You don't know who I am. Let me tell you, I am a policeman and I will look after you and make sure you are very good" - followed by the grandfather - "be strong, blessed and happy. Live as your father and grandfather did" - and the great-grandfather: "be as strong and as honest as your grandfathers and fathers were." Later the father's friends and fellow workers speak. One wishes the baby to grow into an adult as honest as his dear father, to which someone adds: "I ask the Lord to make you into a person like me and your father." An elder colleague concludes: "I wish you a joyful, happy, and prosperous life. I also ask you to be a good lathe operator because we have a shortage of those. I hope by the time you grow up it will be paid better." Not only do male voices dominate this blessed moment of greeting a new life but they speak the language of the patriarchy that recognizes only what is made in its own image. This discourse allows only a male (the strong, happy and honest human) to be an equal member of the community. Symptomatically, the women do not question the legitimacy of this initiation ritual; in fact, one great-grandmother raises it to absurd dimensions: "I wish you a life that takes you to heights, may you become Gagarin. Fly high."

The masculine affective space of familial gathering is a social ritual for itself, as far as it remains blind to the very thing it hopes to honor. This logic of "denial by appropriation" seems to have prevailed not only in the micro-politics of patriarchy but in the practices of bureaucratic empowerment. Tímea N. Kovács's insightful observation about the kitchens of apartment buildings - small 
enough to not even seat members of the nuclear family - is an architectural example of how planners (bureaucrats of space) failed to disrupt deep-rooted notions about familial co-existence and gender-specific role patterns (10). One participant of the debate in Nók Lapja (mentioned above) pointed out the controversy at the foundation of these administrative solutions: "by taking away women from the labor market and locking them within the walls of their homes, the maternity leave conserves the very family model deemed outmoded" (quoted in Tóth 158 , translation mine). ${ }^{5}$ The failure of domestic space to genuinely advance female emancipation was a result of the collaboration between the paternalistic and the patriarchal regimes, most evident in the subordination of welfare policies to national economic considerations. The endless and uniform reproducibility of dwelling spaces to boost statistics of new housing units and to stimulate reproduction rates amongst young couples was hardly accompanied by the design of emancipatory domestic spaces and gender equality. While socialist industrialization brought about demographic requirements satisfied by adopting targeted welfare policies, these measures did not question culturally encoded notions of family: the patriarchy. The next part of my chapter distinguishes between three psychodynamically invested social environments - that of the neighbourhood, the extended family, and the nuclear family (mainly the relationship between spouses) - and proposes that cinema renders legible the character's affective investments in space through describing their confidence in, dependence on, and resistance to, in short, their associations with, patriarchy.

Neighbourly relations as a form of cultural-social-spatial network tell us a lot about patriarchal elements of communal living. The summary Tóth offers of interviews she conducted among female tenants of high-rise blocks points beyond the close companionship we might presume to have existed between people literally living a few feet from each other: "[w] oman workers attributed great relevance to the opinion of their neighbours about their own lifestyles. They intruded into each other's private life. Neighbours provided patterns as to what type of clothes to wear. They also sought to satisfy the expectations of the

5 This opinion is almost identical to Verdery's conclusion about state-socialist gender policies: "radical socialism may have been in reorganizing family structures and roles at one level, at another its paternalism dovetailed perfectly with patriarchal forms central to national ideas elsewhere in the West" (Verdery 79). 
dwelling community through being first-rate wives and by meeting the criteria of female beauty" (151, translation mine). The panoptic gaze invested with normative power, as described here, opened the way for the patriarchal regime to penetrate the female community even in the absence of males and disallowed for the emergence of intimate female spaces. After men left for their workplaces, young mothers on maternity leave attended to house chores and, pressured by strict requirement of having an immaculate household, were relegated to the role of the domestic servant and the housewife, into a subordinate position bearing the weight of the ever-present specter of patriarchal normativity.

Following from Doreen Massey's definition of spatial uniqueness, "the singularity of any individual place is formed in part out of the specificity of the interactions which occur at that location" (168), we could say that uniform spaces and normative lives of the housing complexes disallowed for any singularity as the case of the Agony of Mr. Boróka demonstrates. The homogeneity of spaces, lifestyles and human interactions is foregrounded in the story when the protagonist enters, by mistake, a flat in a neighbouring block. With familiar furniture and similar arrangement of the room he sits down in front of the TV and starts a commonplace conversation with his presumed wife - working in the kitchen - about a refrigerator that needs to be repaired, lunch that is being cooked and the son who needs to be disciplined. Soon the real resident arrives home and the two surprised men have the following conversation:

What are you doing here?

Me? I could ask the same question.

Why would you want to know what I am doing in my own apartment?

I'm awfully sorry, but this apartment is mine. I can recognize what is mine. That picture on the wall, the TV, the sofa, and the woman in the kitchen.

Hold on. Which block do you live in?

D.

Well, this is G, the apartment of Vince Jonyer....

I must have mistaken the apartments. I really am sorry. Everything was so homely in here. Sorry, I meant to say unhomely. (o oo:15:33-0:16:17)

Patriarchal notions of domesticity for Boróka are defined by the familiarity of interior design which includes the housewife, "the woman in the kitchen," as an integral accessory of the flat. In addition, uniformity is identified in stark contrast with singularity, hence giving rise to the shared spatial experience of an "unhomely domesticity": communal living as the state of permanent identity crisis. Its permanence is underlined by the scene that follows, in which 
Boróka returns to his 'real home', behaves the same way and has an almost identical conversation as quoted above. The housing estate in Bacsós portrayal becomes a space without singularity, a neighbourhood populated by the clichéd words, activities, and affections of 'really existing socialism'. In addition, this scene identifies the kitchen as female, while the living room as male space.

Whenever this binary is violated, like in Wall Driller, patriarchy is under threat. In György Szomjas's film a group of bored housewives set up a secret prostitute circuit and offer sexual services for wealthy clients while their husbands are at work. They secretly repossess the living room and the bedroom to avenge patriarchy for having forced them into a barren, aimless, and depressing quotidian existence. Such acts of extramarital sexuality do not simply allow young mothers, as some commentators have suggested, to earn extra money but to regain control over their bodies, free time, and femininity and, at the same time, resist the disempowering label of the housewife. In the eyes of the neighbourhood, however this transgression will be an open act of rebellion against socialist morality, decency and, not least, patriarchal power. The verbal outbursts at the waitress of the café where the transactions took place is less a personal than a generic condemnation of female sovereignty: "As decent men and women we, the majority, are outraged. This woman should be burnt like the witches were in the past, as she brings calamity to domestic values. As a result of her activities alcoholism spreads, men fight with each other and spend their salary on booze instead of their families" (Fekete-Grunwalsky-Szomjas 41). According to the patriarchal logic of binaries, the opposite of the immaculate housewife is the wicked witch, while the alternative of patriarchy is chaos and destitution.

Béla Tarr's Prefab People renders legible another aspect of neighbourhood relations' dependence on the gender regime. The most symptomatic scene to depict shared activities of tenants is a dance party attended by the film's protagonists, a young but emotionally estranged couple. Tarr uses the closeup, the type of shot associated with affectivity and emotionality, to highlight the wife's desperate attempts to capture the attention of her husband, who chooses to dance with a housewife from next door. More and more alcohol is consumed during the night. We see the husband in the company of other men singing a romantic folk song while leaning across the table looking captivatingly at someone whom we presume to be his wife. Yet the camera soon reveals that the person opposite him is a fellow singer and his wife seated further away watches them in frustration. Her spatial position on the periphery of the male company is symptomatic of her unfulfilled desire for tenderness and care, to be recognized by the patriarchal regime as an emotional being. The male bonding ritual of singing together, just like the celebration in Ember's 
Mistletoes, allows women only a withdrawn presence - the position of the spectator and audience - and a form of communal living in which neighbours live alongside and not with each other. Bearing in mind that most Hungarian folk songs talk about deep male devotion for young girls who are beautiful, loyal and obedient, the marginalization of real women and the ritualistic glorification of (stereotypical) imaginary ones is both an escape from the modernurban realities of marital relations to rural traditions of male superiority and the reconstitution of the latter in the former.

\section{Spatial Conflicts Between Generations}

Women amongst themselves, while at the hairdresser, shopping or walking together, discussed a variety of topics ranging from summer holidays to their children's education. However marital problems are rarely touched upon, and never openly tackled in the films. Such concealment of domestic disharmonies and the self-silencing of the sovereign voice of female non-conformity strengthened the patriarchal ideology. While the psychodynamics of female neighbourly relations were founded on superficial communication, male bonding, in the form of drinking, gambling, and entertainment, was not intellectual either, and often shifted into infantilism and aggression. Such communal activities, even if they served the purpose of repressing anxieties and were not compatible with ideals of self-improvement, self-control, and good conduct (features of the new socialist self), still allowed men to release stress. Whenever women sought to act out their frustrations, as those involved in the prostitute circuit depicted by Wall Driller, they were deemed a menace by the neighbourhood.

The ritual of drinking was equally decisive in the interpersonal dynamics among male members of households shared by two or more generations. The turbulent relationship between the father and two sons in Béla Tarr's Family Nest finds temporary peace while consuming alcohol. The roots of their antagonism and the psychological terror they inflict on each other arises from the 'unhomely domesticity' already mentioned in connection with The Agony of Mr. Boróka. The single bedroom flat hosting seven members and three generations of an extended family is a dense space in more than one sense: it is a flat overcrowded by bodies but also a psychological wrestling arena and a discursive space of various interpretations and imaginations of home. Gábor Gelencsér points to the psychological credibility of Tarr's depictions which "almost completely exclude the social environment and concentrates only on the changes faces undergo" (26o, translation mine), and calls it a chamber drama 
of faces that pose but does not answer "what deeply hidden conflicts, identity crises, miseries haunt these people" (26o, translation mine). I fully share this assumption, and would only add that the psychodynamics and conflicts between the desperate and exhausted mother, the alcoholic husband, the spoilt daughter, and the hypocritical father-in-law are embedded in and arise from their different use and notions of space.

The grandparents represent the generation with a stable income, a flat of their own, and a socio-economic security, which they believe entitles them to lecture family members on honest work, the normal conduct of life, and domestic happiness. The petit bourgeoisie instincts of the homeowner are most prevalent in the case of the grandfather, who speaks about his right to privacy in the morning, and tries to flatter a lady with cheap compliments to the point of harassment in the evening. The character's contradictions and his self-ascribed position of the assertive patriarch need to be considered collectively. More than privacy, he needs a space populated by submissive people who willingly idolize him and blindly accept his demands, values, and moral superiority. By the same token, he agrees to share the flat with his son's family not because of his frequently proclaimed deep emotional attachment to his granddaughter, but because he can easily assert his will on the child and continue the emotional blackmail of the rest of the family. In addition, he uses his superior financial position to deprive his son and daughter-in-law the chance to serve as positive role models for their daughter, and almost poses as the biological father to his granddaughter, ascribing to himself direct parental authority. In his patriarchal perception of domesticity, the home should be the space of total obedience, the spatialization of undisputed authority. When this authority is contested by his daughter-in-law (Irén), he will transform into a sneaky manipulator constructing fake narratives of her infidelity and scheming until the emotional estrangement fully consumes his son's marriage.

Irén is the rebel figure of the younger generation, and resists the instructive manners of the patriarchal father-in-law with a strong sense of maternal responsibility. Almost every aspect of her personality stands in stark contrast with her father-in-law's temperament. Her fluid-permissive morals and bohemian attitudes oppose his rigid principles and petit bourgeois mentality, while her prodigal attitude to money could not be more different from that of the penny-wise older generation. The seminal difference, nevertheless, lies between the maternal-feminine affections, Irén's emotional honesty and the manipulative rationality of the paternalistic regime. The gendered nature of these agencies reaches beyond the scope of the extended family demonstrated by the scene set in the city council's housing department. Tarr emphasizes the spatial hierarchy between the crowded corridors where young mothers queue 
with their applications for council housing ${ }^{6}$ and the spacious office occupied by the technocratic male bureaucrat, the functionary of space with the power to decide who is entitled to council homes (that are not even built) and who is not. Both the administrator - who measures, evaluates, categorizes clients' eligibility for flats - and the father-in-law - who regulates who can stay out and for how long, when one can bring friends, cook and sleep - exercise on the local level the power of patriarchy to penetrate and supervise private lives. The housing official, for instance, urges Irén to bear more children and hence increase her chances for a council flat. This twisted logic which objectifies human life and treats it like a manageable resource is instinctively rejected by Irén who, at one point, bursts out:

We exist because our parents wanted us to exist. One is so happy with a child! When we are sad, a child makes us happy. They are so gentle. All this social policy nonsense they talk about all the time! One doesn't bear children just to increase the population but because one wants to. It is so good to have a child one loves. (01:27:22-01:27:55)

Despite their contrasting lifestyles and mind-frames, both Irén's and her father-in-law's notions of domestic space are shaped by personal pathologies. The male character's incorporation of patriarchal logic is a strategy to offset the psychological damage of his inferiority complex: the wish for a home with full power and authority probably compensates for his failure to prove his professional aptitude at the workplace. Thus, patriarchy serves him well to keep frustrations at bay and to repress his identity crisis. As for Irén, her yearning for her own home to repair her marriage and create a loving family atmosphere seems to be the constitutive factor. Her imaginations about domestic space are formed within the pathology of escapism and rely on ideals that are selfdeceptive to the degree that they disallow her to assess the situation realistically and examine her own responsibility in failures. I regard this as a utopian notion of domesticity, the shortcomings of which I will explore next with reference to the psychodynamics between spouses.

6 The scene in question is an accurate illustration of the gendered division of labour, prescribing women the inferior role to queue at social benefit offices (or stand in food lines), while men did work considered as superior. 


\section{There Is no Place Like Home}

Family Nest is about domestic space which despite being absent still stands in between people. The characters of The Prefab People seem to have resolved the central problem of Tarr's previous film. Although they live in their own flat located on a new housing estate made of panel high-rise buildings, this domestic space is burdened by regular quarrels and bitter from the emotional isolation of the married couple. The two films form a whole and, whereas the first features people dreaming about home as the epitome of an independent, balanced, and affectionate family life, the second recognizes this promise as unfulfillable. The patriarchal regime in The Prefab People takes the shape of spatialized affect that is maternal claustrophobia, which the character of the wife/mother describes as follows:

You come home, and I try to be humorous and in a good mood. Dinner and the kids are both ready, you don't have to do anything. You don't have to take them to school, check their homework. When you take the kid to see a football match, go for a walk or to the sweet-shop, you both have a good time. I always have to do the hard stuff, I'm always jumpy with him, always quarrelling and I can't, I can't control myself ... All the time I have to control myself and be patient. In front of you, in the shops, greet everyone with a smile. I can't take it anymore. I can't stand being either with one of them or with both. You're with him when you feel like it. If you don't, you just lie down, read the paper, watch TV, listen to the radio, or go out. You can go out whenever you feel like and wherever you want to. (oo:13:50-0o:15:01)

The home becomes a trap after realizing she is left on her own with the house chores and anxieties, when she loses the strength to cling on to the imaginary and utopian promises she used to embrace, and can no longer overlook the actual and real limits of her existence: the fact that the domestic space is a place that lacks emotional attachment. When the husband replies to the above accusations, he makes reference to the grueling monotony of the workplace and tries to calm his wife's frustrations by promises of higher income and more money to spend: "we'd have a car within a year" (The Prefab People oo:52:58oo:53:0o), "in the second year we might save up enough money to buy a house with a garden" (oo:53:10-0o:53:17). Patriarchy's answer to maternal claustrophobia is yet another (utopian) promise, a commitment to consumerism as the presumed solution to distress and the key to eternal happiness. It takes assurance in an unforeseeable future, and fetishizes it through amassing material 
wealth and status symbols: it keeps talking about where the family is heading, because it is less and less sure where it stands. Robi understands Judit's entrapment and claustrophobia, but he is unable to address it with empathy, and continues to yearn for the future and avoid the present. When this strategy fails and the masculine identity crisis takes concrete shape, he takes the easy escape route (the freedom of movement provided by the patriarchal regime) in an attempt to leave the family behind: "You're fed up? And you just say, I'm going? ... Where do I go, tell me, what's going to happen to me? How do you imagine that, tell me? Where do you imagine I'll go to? When I've had enough where do I go to, tell me? ... You think you can just say you're off?" (o1:o6:33o1:06:53) Escaping from loud children and exhausted wives is a recurring motif of the films. Hardly does the character of the husband in Family Nest arrive home after being discharged from a two-year army service, when he runs off to the pub with his brother, but only after they sexually assault a lady friend in the corridor of the apartment building whom they had offered to walk home. In Wall Driller Géza does not hesitate much to take the first escape route he is offered when his wife burst out one evening:

I don't know and I don't care either. I'm bored with it, do you understand me? Bored! Leave me alone, Géza! Hell, you spend no time at home. You don't give a shit about the kids. And I spend my days by your bloody telephone which never rings anyway. ... Don't explain anything to me, Géza because you don't have to explain anything to me, because I know very well what the situation is. We only have this bloody weariness and nervousness ... And Géza, go to hell! Listen then, I'll leave.

As you please!

I'm gone.

Just slam the door when you are gone! (oo:58:37- oo:59:53)

In the end, neither does the husband deserts the family, nor do they reconsider their approach to gender roles or refute their inherent hierarchy. Spouses will continue to have the same fights over and over again, and whenever mothers feel they have been forced into concrete cages, the patriarchal regime will continue to feed them empty promises of material welfare and address both female angst and the emotional vacuum of marital relationships with patronizing cynicism. In The Prefab People, Tarr lays bare the correspondence between the idealistic male visions of the future and the similar imaginations of the socialist system as the father tries to explain the Marxist principles of history to his elder son: 
Imperialism is the most developed form of capitalism and was followed by socialism. We live in socialism today. A more developed stage will be communism when ... [confused] Well, in socialism everyone gets ... [even more confused] or rather in socialism your needs ... No, in socialism you get as much as what you work, while in communism, everyone will get everything they need. (oo:23:42-00:24:23)

The confusion of the character is most visible when talking about the contemporary social context, when trying to grasp the essence of his most imminent reality in time and space. His inability to do that is reminiscent of his failure to address the roots of the domestic crisis, while his eventual definition of socialism as a space yearning for an illusory elsewhere is again an apt expression of his own experience of lacking meaning and emotions in life. Until the logic of utopian socialism continues to characterize the psychodynamics of domestic space, patriarchal males will carry on making promises and, in the process, justify and conserve mechanisms and strategies of how not to face their partner's or their own identity crisis.

\section{Conclusion}

Cinema's ability to capture living bodies as much as their experience of how it feels to be alive makes screen products into a vast resource of studying affective configurations and structures of feelings. But since these bodies exist in a shared social context defined by interpersonal relations, material and discursive givens, films also inform us about the historical, social and spatial creation of affects. More bluntly put, cinema apprehends people's capacity to affect and to be affected in specific spaces, historical epochs and under the guidance of particular norms.

This chapter focused on cinematic articulations of how mothers with young children feel in domestic space which, to a large extent, owes its existence to state socialist welfare policies. These policies, as the films testify, are grounded on and foreground a gender regime, valuing industrial and administrative male work over domestic work and parenting, making women dependent on their elders' and spouses living facilities and income, furthermore disallowing female emancipation by setting up standards as to how young mothers should look, behave and feel. I argued that the generational and personal conflicts that arise from this gender regime involve not only a struggle in and over domestic space, but different and often contradictory affective investments into the home and the family. For young mothers, it becomes a site of entrapment 
after it ceases to provide for emotional union, while husbands perceive it as a site of identity crisis, that can be coped with by making promises of a better future, the very strategy utopian socialism adopted to domesticate people's desire for autonomy and turn it into the willful acceptance of dependency.

\section{Works Cited}

Bacsó, Péter. Forró vizet a kopaszra! (The Agony of Mr. Boróka). Budapest FilmstúdióMAFILM/Mokép, 1972.

Bakay, Eszter. “The Role of Housing Estates' Green Surfaces in Forming the City Climate of Budapest." Applied Ecology and Environmental Research vol. 10, no. 1 (2012): 1-16.

Crowley, David. "Warsaw Interiors: The Public Life of Private Spaces, 1949-65." In Socialist Spaces: Sites of Everyday Life in the Eastern Bloc. Edited by David Crowley and Susan E. Reid. Oxford: Berg, 2002. pp. 181-206.

Csizmady, Adrienne. "Lakótelep és társadalmi szegregáció." ("High-rise Housing Districts and Social Segregation") Szociológiai Szemle (1996/3-4): 96-132.

Csizmady, Adrienne. A lakótelep. (The High-rise Housing District) Budapest: Gondolat Kiadó, 2003.

Egedy, Tamás. "A társadalmi kirekesztés és a lakótelepek." ("Social Marginalization and High-Rise Housing”) Tér és Társadalom 15 (2001/1): 91-110.

Egedy, Tamás. "Kiskedvencből mostohagyerek? A lakótelepek helyzete" ("From Being Favorites to Being the Odd One Out: High Rise Housing Districts Today") Beszélo" vol. 10, no. 3-4 (Mar.-Apr. 2005): 77-88.

Ember, Judit. Fagyöngyök (Mistletoes). Film. Balázs Béla Stúdió-Hunnia Filmstúdió/ Mokép, 1978.

Fekete, Ibolya, Grunwalsky Ferenc and Szomjas György. "Falfúró: filmnovella." ("Wall Driller: A Film Novelette") Filmvilág 28.6 (1985): 40-51.

Flanagan, Maureen, A. Valiulis, and Maryann Gialanella. "Introduction: Gender and the City: The Awful Being of Invisibility." Frontiers vol. 32, no.1 (2011): xiii-xx.

Gelencsér, Gábor. A Titanic zenekara. (The Band of the Titanic) Budapest: Osiris, 2002.

Kovács, N. Tímea. "Lakótelepek - a modernitás laboratóriumai. Bevezető." ("High Rise Housing Districts - Laboratories of Modernity. Introduction") Lakótelepek - a modernitás laboratóriumai, edited by Kovács N. Tímea. Budapest: Kijárat Kiadó, 2008. pp. 7-14.

Lefebvre, Henri. The Production of Space. Oxford: Blackwell, 1991.

Massey, Doreen. Space, Place and Gender. Minneapolis: U of Minnesota P, 1994.

Murai, András, Tóth Eszter Zsófia. "Magánörömök, közállapotok: a szexualitás ábrázolása a nyolcvanas évek magyar filmjeiben." ("Personal Pleasures and Social 
Conditions: The Representation of Sexuality in 1980s Hungarian Cinema") Médiakutató vol. 12, no. 2 (2011): 7-21.

Sándor, Horváth. "A lakótelepek népe és a bűn metaforái: a Mária Valériától a csövesekig." ("The Folks of High-Rise Housing Districts and Metaphors of Crime: from Mária Valéria to the Ragged Youth") Lakótelepek, a modernitás laboratóriumai, edited by Tímea N. Kovács. Budapest: Kijárat Kiadó, 2008. pp. 83-100.

Soja, Edward W. "Thirdspace: Expanding the Scope of the Geographical Imagination." Human Geography Today. Ed Doreen Massey, John Allen and Phillip Sarre. Malden: Blackwell, 1999. pp. 26o-2.

Szelényi, Iván and Konrád György. Az új lakótelepek szociológiai problémái. (The Sociological Problems of New High-Rise Housing Districts) Budapest: Akadémiai Kiadó, 1969.

Szomjas, György. Falfúró. (Wall Driller). Hunnia-Mafilm/Mokép, 1985.

Tarr, Béla. Családi tüzfészek. (Family Nest). Balázs Béla Stúdió/Mokép, 1979.

Tarr, Béla. Panelkapcsolat. (The Prefab People). Balázs Béla Stúdió-MAfilm-M TVFMsTársulás Stúdió/Mokép, 1982.

Tóth, Eszter Zsófia. Kádár leányai. (Kádár's Daughters) Budapest: Nyitott Könyvmühely, 2010.

Verdery, Katherine. What Was Socialism, and What Comes Next? Princeton: Princeton UP, 1996. 